\title{
FINITE ELEMENT ANALYSIS OF ADHESIVE BONDS USING THE COHESIVE ZONE MODELING METHOD
}

\begin{abstract}
This paper covers the subject of FE modeling of adhesive joints, which is gaining more and more attention in contemporary industry, especially in the aerospace and automotive sectors. This technique of creating structural connections possesses many advantages over mechanical or welding methods and it seems that it will be exploited extensively in the future mechanical design. The ability of joining dissimilar materials decreased minimum member cross-section size and corrosion inertness can be considered as its most important features. However, in the era of virtual prototyping, it is necessary to conduct reliable computer-assisted analyses of these types of joints. It is because most of the contemporary structures are developed as numerical models first, and only the final product is prototyped physically, to validate the simulation results. The aim of this paper is to demonstrate how to elaborate reliable and accurate adhesive joint models, using a cohesive zone modeling (CZM) method in conjunction with shell-based models. The major profitable consequence of using this modeling technique is that it results in a relatively small number of spatial degrees of freedom, therefore allows for short computational times.
\end{abstract}

Keywords: glues, adhesives, modeling, CZM, lightweighting

\section{ANALIZA MES POEACZEN KLEJONYCH Z WYKORZYSTANIEM MODELU KOHEZYJNEGO}

Niniejszy artykut opisuje metodę modelowania numerycznego połaczeń adhezyjnych, które $w$ ostatnim czasie zyskujq duża popularność, szczególnie $w$ przemyśle lotniczym i samochodowym. Ta metoda spajania elementów konstrukcyjnych ma wiele zalet przewyżsajacych tradycyjnie wykorzystywane połaczenia mechaniczne oraz spawanie. Do najważniejszych zaliczyć można możliwość łqczenia materiatów o odmiennym składzie chemicznym, możliwość zmniejszenia minimalnego wymiaru przekroju poprzecznego taczonych elementów oraz odizolowanie taczonych elementów, co chroni je przed korozja elektrochemicznq. Wspótczesne trendy projektowania zakładaja petny rozwój konstrukcji w formie modeli komputerowych, a rzeczywisty prototyp powstaje dopiero jako produkt finalny, shuzac walidacji otrzymanych wyników. Dlatego też, celem badań opisanych $w$ niniejszej pracy było przedstawienie wykorzystania modelu połaczenia adhezyjnego zbudowanego na podstawie elementów typu powtokowe, oddajacego $w$ doktadny sposób zachowanie tego rodzaju spoin. W artykule opisano wykorzystanie metody modelowania kohezyjnego (CZM), której podstawowa zaleta jest możliwość implementacji nawet $w$ zlożonych przypadkach, bez znacznego wydlużenia czasu ich analiz.

Stowa kluczowe: kleje, adhezja, modelowanie, CZM, zmniejszanie masy

\section{INTRODUCTION}

The recent trends in the automotive sector have focused on the so-called lightweighting, i.e., decreasing of the structural mass of a vehicle without the loss of its mechanical performances, as described by Korta and Uhl (2013). As shown by many researchers in the field, the most significant mass improvements can be achieved by the application of modern structural materials, like high-strength steels, magnesium and aluminum alloys and polymer matrix composites (PMC). These can provide considerable weight gains without deterioration in strength or stiffness properties. However, due to technological and economic issues, it is assumed in a modern design that only part of the construction is substituted by these substances. This results in simultaneous exploitation of multiple dissimilar materials in order to build a vehicle body.

Although advantageous, the so-called multi-material design possesses some drawbacks, among which joining is one of the most evident. Classical methods of creating permanent connections between the consecutive parts of a structure, e.g., spot welding, are not applicable when elements made of dissimilar materials are to be joined (e.g., glass fiber reinforced polymer with aluminum alloy). In such cases, two types of methods can be used: mechanical and adhesive joining. Although well known in engineering, the former has many drawbacks. It introduces additional mass to the structure, creates areas with local stress concentration which forces the designer to use thicker elements, which can withstand the local loads. Furthermore, if materials characterized by different electrode potentials are in contact, galvanic corrosion can occur. This can be omitted only by using additional, chemically inert separators between the joined parts. Finally, it also influences the aesthetics, because mechanical fasteners are often visible by the naked eye.

Adhesive joining provides an opportunity to omit these problems. It is suitable for application on dissimilar

* AGH University of Science and Technology, Faculty of Mechanical Engineering and Robotics, Department of Robotics and Mechatronics, Krakow, Poland; korta@agh.edu.pl 
materials, providing a reliable and firm bond, as described by Korta et al. (2015). Differently than in the case of mechanical fasteners, large application areas influence positively the load transfer paths, resulting in low stress gradients. This property can be used to decrease the thickness of connected elements. Smooth stress distribution obtained by the application of adhesives can also be exploited to control the crash characteristics of a structure, as presented by Lanzerath et al. (2009). Another important advantage is connected with the economic aspects of adhesive bonding. Since it requires simple tooling and consumes small amounts of energy, it is perceived as a cheap alternative to other joining methods. According to the needs, structural glues can provide elastic connections, which compensate unwanted vibrations, improving structural noise, vibration, and harshness (NVH) characteristics. Additionally, a layer of adhesive between the connected elements separates them, preventing the galvanic corrosion.

With the extensive use of modern structural materials in structural engineering, the subject of adhesive bonding has gained much attention among researchers. Rudawska (2009) described how the surface treatment of the adherents can influence the epoxy-based joint strength. The applicability of structural glues to composite materials was discussed by Lee et al. (2009) on the example of pultruded elements made from carbon fiber reinforced polymer (CFRP). The author studied the sensitivity of the connections towards geometrical parameters by changing the lap area and glue layer thickness. The fatigue behavior of adhesive joints was studied by Godzimirski and Komorek (2007) and Godzimirski and Rośkowicz (2008). The resistance of joints towards small, cyclic loading forces is crucial for the durability of the design. The authors demonstrated in their work how this is influenced by the joint shape and bonding parameters. Multi-material bonded joints, consisting of steel and glass fiber reinforced polymer (GFRP) were investigated by Jiang et al. (2013). Specially prepared samples were loaded in shear and tension simultaneously, which allowed for a thorough assessment of their static behavior. Additionally, the authors elaborated finite element (FE) models which were used to understand the stress distribution in the joint. To accurately reflect the complex stress state in the bond line, the authors used 8-node linear brick elements, with one integration point and hourglass energy control. Rudawska (2013) presented a thorough description of aspects regarding the FE modeling of this type of connections. This author presented an FE analysis of a single lap joints loaded in shear, observing the fracture path and stress distribution. The joint was modeled by three-dimensional volume elements, the behavior of which was governed by the traction-separation material model. Other authors covered this subject as well: Sugiman et al. (2013) presented a process of elaboration of the FE model of adhesive joints considering the process of environmental aging. The joint consisted of two types of volume finite elements: the upper and lower adhesive layers were built from brick elements. These two separate segments were connected together, in the middle of the bonding line, by threedimensional cohesive elements. Tran et al. (2014) used FE modeling to carry out numerical optimization of the shape of wooden finger joints, in order to understand the stress propagation pattern in this type of connections, to improve its strength. Hazimeh et al. (2014) described a process of building and testing numerical models of adhesive bonds, which were exploited to study the dynamics of the joints. The adhesive layer was built up using 4 elements through its thickness, resulting in the smallest element dimension equal to $0.025 \mathrm{~mm}$. However, on the edges of the bond, the mesh was refined to the size of $5 \times 25 \times 100$ micrometers. The elaborated models were subsequently used to analyze connections between composite adherents, subjected to dynamic, impact loads.

As described above, to obtain accurate results for the analysis of adhesive joints, the models are usually meshed in extremely fine manner, using volume (brick) elements for the discretization of adhesive and adherends. This method allows for a thorough examination of joint stress pattern and strength, but precludes this type of FE simulation from real-life industrial applications, in which large scale systems often need to be assessed. It is especially evident in the case of the mesh size used by Hazimeh et al. (2014). Although it was elaborated for and tested under impact loads, for obvious reasons it could not be used to analyze the behavior of a majority of full-size mechanical systems working under the same conditions (e.g., car vehicles or ceiling joists) and designed using adhesives.

This paper describes the studies aimed at filling this gap in the field of industrial engineering, covering the subject of a simplified yet accurate numerical modeling method of adhesive joints. The proposed technique is based on twodimensional contact elements combined with a bi-linear material model, cohesive zone method (CZM) and two-dimensional shell elements, which can be used for analyzing mechanical structures under complex loads. The subsequent paragraphs present all the steps necessary to build a reliable and accurate model of adhesively bonded joints and describes the experimental campaign aimed at the validation of the proposed technique.

\section{MODELING METHOD}

In order to model adhesive bonds using the finite element method, the cohesive zone modeling (CZM) technique can be adopted. It is an approach which is applicable to the problems of bonding and lamination of materials, and can be used to simulate debonding, delamination or crack propagation. A thorough description of the CZM technique can be found in ANSYS Theory Manual (2007), while the following sections present its general overview. 
The CZM method is based on so-called interface elements, which are modeled as contact shell or volume elements between the bonded surfaces. During the computations, the stiffness of a CZM connection undergoes iteration-to-iteration modification, following the traction-separation law, which assumes three distinct failure modes: separation (in the normal direction), shear (in-plane direction) and mixed mode (consisting of the previous two). The traction-separation models are based on maximal allowable normal and shear stresses and separation in these directions causing failure of the bond. The bi-linear model used throughout this article was based on shell contact elements, while its exponential counter model can be modeled as hexagonal bricks. The former method was proposed by Alfano and Crisfield (2001) and described in this reference thoroughly.

The normal and shear stresses in a joint described using the bi-linear material model are calculated, respectively, by equations (1) and (2):

$$
\begin{gathered}
\sigma_{n}=K_{n} u_{n}\left(1-d_{n}\right) \\
\tau_{t}=K_{t} u_{t}\left(1-d_{t}\right)
\end{gathered}
$$

where:

$\sigma_{n}$ and $\tau_{t}-$ the normal and shear stresses,

$K_{n}$ and $K_{t}-$ stiffness in normal- and tangential direction, $u_{n}$ and $u_{t}-$ relative displacement of the bonded surfaces, $d_{n}$ and $d_{t}$ - the parameters calculated in accordance with equations 3 and 4 .

$$
\begin{aligned}
& d_{n}=\left(\frac{u_{n}-\bar{u}_{n}}{u_{n}}\right)\left(\frac{u_{n}^{c}}{u_{n}^{c}-\bar{u}_{n}}\right) \\
& d_{t}=\left(\frac{u_{t}-\bar{u}_{t}}{u_{t}}\right)\left(\frac{u_{t}^{c}}{u_{t}^{c}-\bar{u}_{t}}\right)
\end{aligned}
$$

where:

$\bar{u}_{n}$ and $\bar{u}_{t}-$ separations corresponding with maximal allowable stresses in normal and shear directions,

$u_{n}^{c}$ and $u_{t}^{c}-$ maximal allowable separation in normal and shear directions for the joints.

The mixed mode of failure is described by modified equations for normal and shear stresses, given by equations (5) and (6):

$$
\begin{aligned}
& \sigma_{n}^{\text {mixed }}=K_{n} u_{n}\left(1-d_{\text {mixed }}\right) \\
& \tau_{t}^{\text {mixed }}=K_{t} u_{t}\left(1-d_{\text {mixed }}\right)
\end{aligned}
$$

Here, $d_{\text {mixed }}$ is given by equation (7):

$$
d_{\text {mixed }}=\frac{\Delta_{\text {mixed }}-1}{\Delta_{\text {mixed }}} \beta
$$

where $\Delta_{\text {mixed }}$ and $\beta$ are expressed by equations (8) and (9):

$$
\begin{gathered}
\Delta_{\text {mixed }}=\sqrt{\left(\frac{u_{n}}{\bar{u}_{n}}\right)^{2}+\left(\frac{u_{t}}{\bar{u}_{t}}\right)^{2}} \\
\beta=\left(\frac{u_{n}^{c}}{u_{n}^{c}-\bar{u}_{n}}\right)=\left(\frac{u_{t}^{c}}{u_{t}^{c}-\bar{u}_{t}}\right)
\end{gathered}
$$

The last condition is forced automatically by scaling joint stiffness in the normal- and tangential direction.

\section{EXPERIMENTAL DERIVATION OF BONDED JOINT STRENGTH}

In order to build a FE CZM model of an adhesive joint, physical specimens were prepared according to the ASTM standards: D897 for shear and D3165 for tensile tests. The bonded material was EN AW 5083 aluminum alloy. According to the standard restrictions, ten and twenty coupons were prepared for tensile and shear tests, respectively.

Prior to bonding, the specimens were treated by abrasive paper, cleaned, and degreased. The bonding was realized within 15 minutes after cleaning, to ensure that the surface of the tested material would not oxidize, covering itself with a natural layer of aluminum oxide $\mathrm{Al}_{2} \mathrm{O}_{3}$. The bonding substance used in the tests, was Hysol $9492^{\circledR}$ epoxy structural adhesive. After bonding, the specimens were conditioned in room temperature and humidity for fourteen days.

The specimens were tested on an Instron 8872 testing machine. A quasi-static load was applied with a velocity of $1.27 \mathrm{~mm} / \mathrm{min}$. Figure 1 depicts the tested elements mounted to the appliance used to assess their strength.

The results obtained from measurements are presented in figure 2. The calculated mean values were equal to 18.10 $\mathrm{MPa}$ and 11.10 MPa, for the tensile- and shear test, respectively. The standard deviations for these results were equal to $6.32 \mathrm{MPa}$ and $0.72 \mathrm{MPa}$, which could be caused by specimen surface preparation and conditioning environment. However, this lack of accuracy does not influence the results presented in this paper, because the focus of the efforts described here was put on numerical modeling issues.

Another important information obtained from the quasi-static tests is the separation of the bond which takes place when debonding occurs. It is also essential for the proper definition of the CZM model. The measured separation mean values were: $0.29 \mathrm{~mm}$ and $0.34 \mathrm{~mm}$ for the tensile and shear tests, respectively. The standard deviations of these results were equal to $0.099 \mathrm{~mm}$ and $0.129 \mathrm{~mm}$, as is presented in figure 2. The above-described values depicting the examined adhesive joint strength and deformation were taken as the inputs for the subsequently elaborated FE model. 

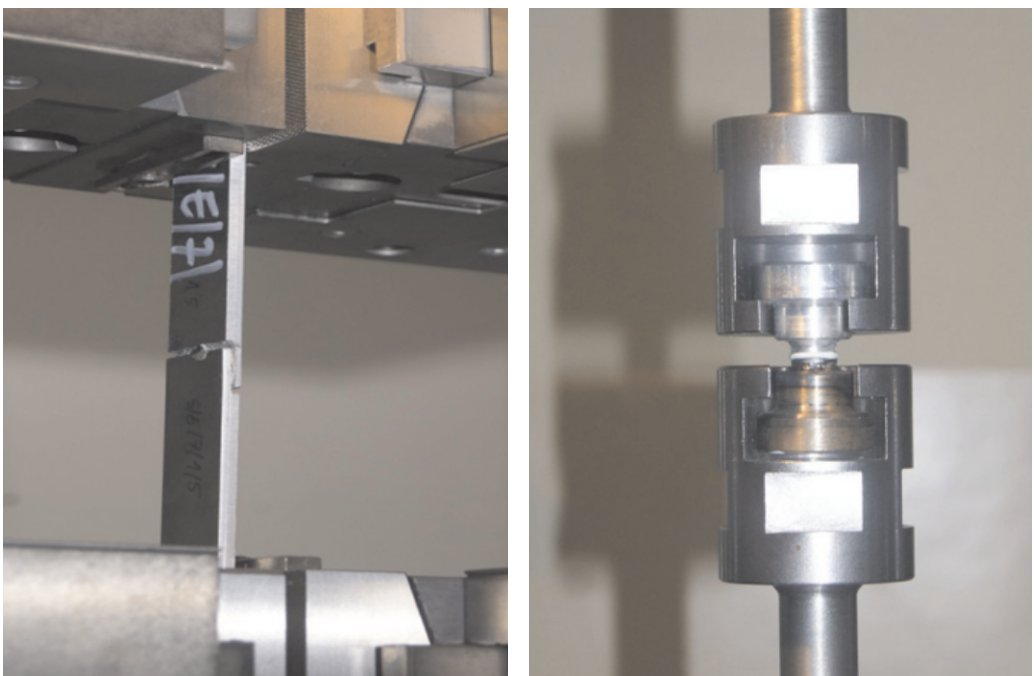

Fig. 1. Shear tests according to ASTM D897 standard (left picture), and tensile test according to ASTM D3165 standard (right picture)
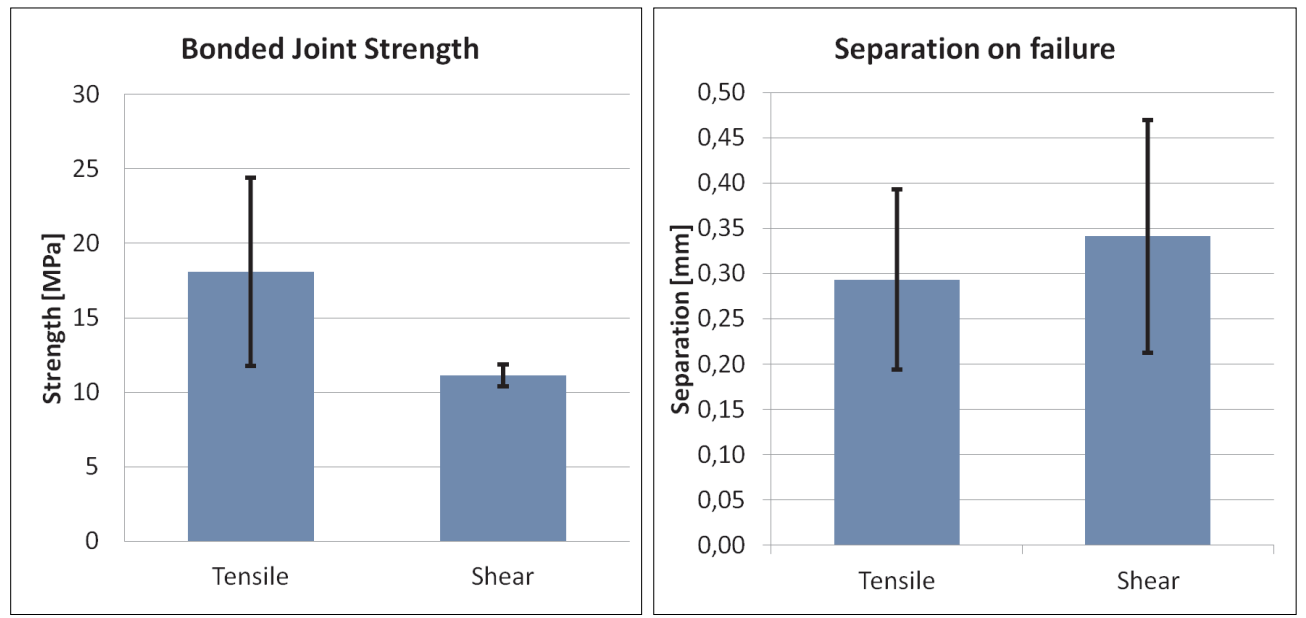

Fig. 2. The strength and separation measured for the bonded joint tested in tensile and shear

\section{VERIFICATION OF THE PROPOSED NUMERICAL MODELING METHOD}

In order to build a numerical model of a bonded joint, the above-described CZM method was used. Two models were prepared for this purpose, in the Altair HyperMesh environment and post processed in the Altair HyperGraph software. The assumption was to compare the results obtained for 4-node shell elements, with the output of analyses carried out with 8-node bricks. The former type of finite elements is characterized by 6 degrees-of-freedom (dof) in each corner node, while the latter, three-dimensional volume elements, by 3 translational dof per node. The size of the finite elements was $1 \mathrm{~mm}$ length per edge in all cases, except for the bricks representing the adhesive layer, in the case of which the height - i.e., the element dimension measured perpendicular to the adhesive layer surface - was equal to $0.05 \mathrm{~mm}$.
All the material constitutive models were isotropic, characterized by the following parameter values:

- aluminum adherends: stiffness $E_{\mathrm{Al}}=69.00 \mathrm{GPa}$, Poisson's ratio $v_{\mathrm{Al}}=0.33$,

- HYSOL $9492^{\circledR}$ adhesive: stiffness $E_{\mathrm{H} 9492}=6.70 \mathrm{GPa}$, Poisson's ratio $v_{\mathrm{H} 9492}=0.30$.

Additionally to the described two types of coupons examined in shear, a tensile test was carried out on a brickbased model. Due to the shape of the adherends used in this type of joint, it was impossible to carry out the same analyses on shells. Nonetheless, the results obtained were useful for the validation of the CZM-based FE numerical representation of the adhesive connections.

In order to understand the applicability of shell elements to the modeling of adhesive joints problems, a comparison was done between shell and brick discretized joints. The shell type of FE is utilized to describe thin-walled 


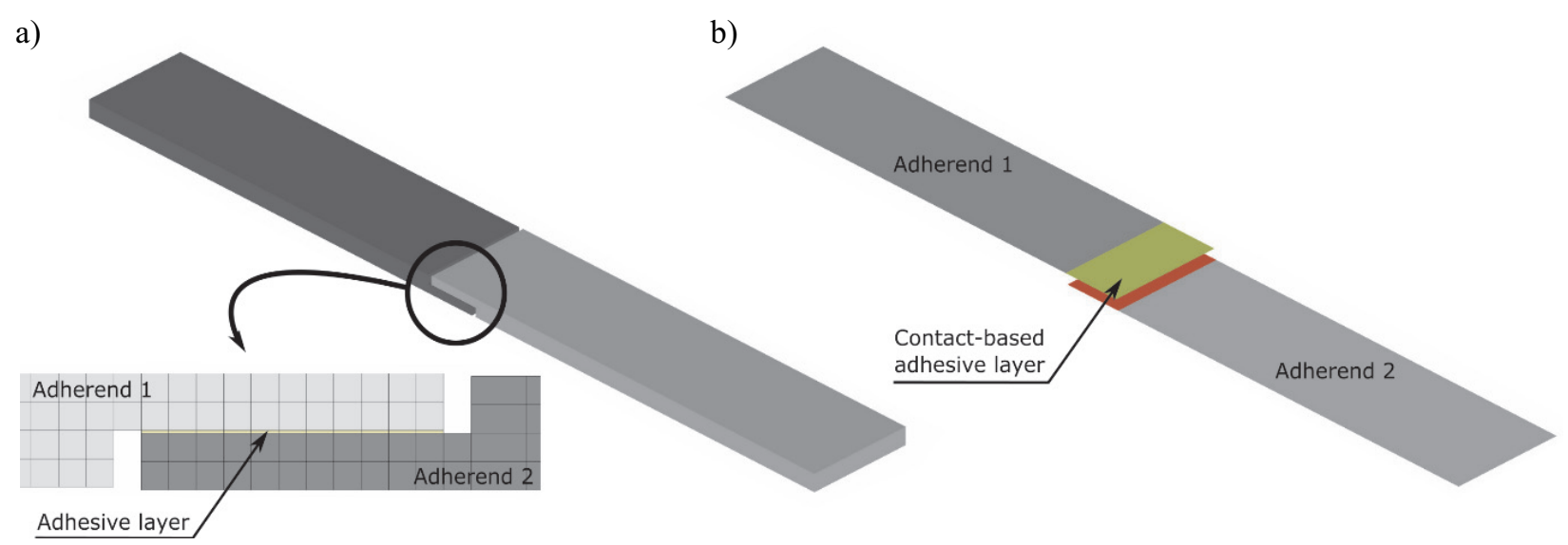

Fig. 3. FE models of specimens tested in shear: a) three-dimensional brick-based, b) two-dimensional shell-based, discretization of the adherends and adhesive

structures on a daily basis, across many industries, including automotive and aviation sectors. The shell discretization allows for the lowering of the number of active dof's in the model, therefore deceases the time needed for the results to converge. Furthermore, since in the presented methodology the CZM material model is defined in conjunction with contact elements, the mesh of the connected components does not have to be congruent, which is not true when brick elements are utilized. The adhesive joint modeling method described in this paper is suitable for building shellbased FE models, while a three-dimensional brick representation of a glue layer requires the discretization of adherends using the same type of elements (compare figure 3), which is unacceptable when more complicated models are to be analyzed.

By using the strength and stiffness values obtained in the experiments described in the preceding section, the appropriate CZM models were defined and used to join the adherends modeled as depicted in figure 3 . The FE models of the tested specimens and the corresponding results are shown in figures $4-6$. a)

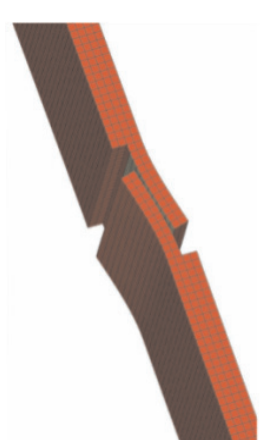

b) a)

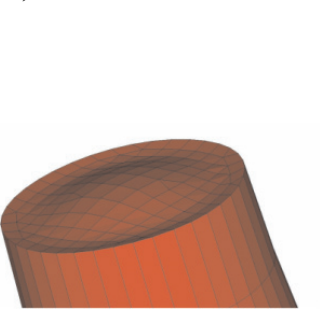

b)

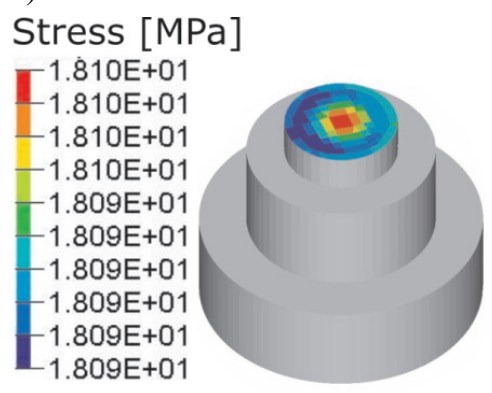

Fig. 5. Results of the brick FE analysis of the aluminum-aluminum coupon bonded by HYSOL $9492^{\circledR}$ adhesive and loaded in tension: a) the coupon deflection (scaled),

b) stress distribution in the joint during rupture a)

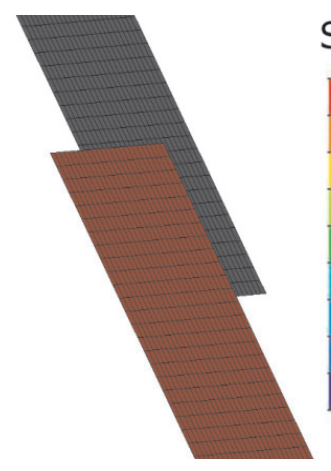

b)

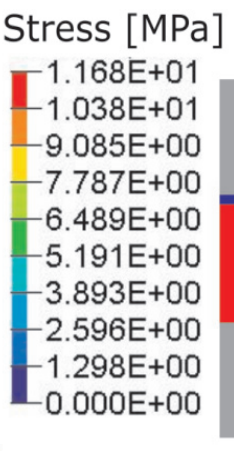

Adherend 1

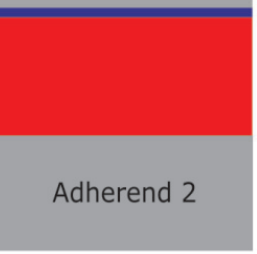

Fig. 6. Results of the shell FE analysis of the aluminum-aluminum coupon bonded by HYSOL $9492^{\circledR}$ adhesive and loaded in shear: a) the coupon deflection (non-existent, because of the element type used), b) stress distribution in the joint during rupture

Table 1 compares the results obtained and depicts the differences in their accuracy. As can be seen, the results obtained by brick elements in tension were very precise, showing no discrepancy between experimental and FEM
Fig. 4. Results of the brick FE analysis for the aluminumaluminum coupon bonded by HYSOL $9492^{\circledR}$ adhesive and loaded in shear: a) the coupon deflection (scaled), b) stress distribution in the joint during rupture 
Table 1

Comparison between experimental and numerical results obtained for specimens tested in shear and in tension

\begin{tabular}{|l|c|c|c|c|c|}
\hline \multicolumn{1}{|c|}{ Results } & Experimental & $\begin{array}{c}\text { Numerical } \\
\text { (BRICS) }\end{array}$ & $\begin{array}{c}\text { Relative error } \\
\text { (BRICKS) }\end{array}$ & $\begin{array}{c}\text { Numerical } \\
\text { (SHELLS) }\end{array}$ & $\begin{array}{c}\text { Relative error } \\
\text { (SHELLS) }\end{array}$ \\
\hline Ultimate tensile strength & $18.10 \mathrm{MPa}$ & $18.10 \mathrm{MPa}$ & $0.00 \%$ & - & - \\
\hline Separation in tension & $0.29 \mathrm{~mm}$ & $0.28 \mathrm{~mm}$ & $-3.45 \%$ & - & - \\
\hline Ultimate shear strength & $11.10 \mathrm{MPa}$ & $11.21 \mathrm{MPa}$ & $0.99 \%$ & $11.68 \mathrm{MPa}$ & $5.23 \%$ \\
\hline Separation in shear & $0.34 \mathrm{~mm}$ & $0.35 \mathrm{~mm}$ & $2.94 \%$ & $0.33 \mathrm{~mm}$ & $-2.94 \%$ \\
\hline
\end{tabular}

analysis results. This was a result of the coupon shape: very stiff adherends underwent only small deflections during the tests and therefore, the stress measured on the strength machine corresponded exactly with the tensile characteristics of the examined adhesive. This, however, was not the case in the tensile tests. The coupons, although thick, deflected to some degree when loaded, and in consequence, the adhesive layer was under a complex load state, when shear strength was measured. This data was an input for FEM analysis and, therefore, caused small inaccuracies of the results. For the brick-based model, the relative error between the experimental and FEM results was equal to $0.99 \%$, which constituted for $0.11 \mathrm{MPa}$ of internal adhesive stress. The analysis of the shell model resulted in $11.68 \mathrm{MPa}$ of shear stress, showing $0.58 \mathrm{MPa}$ difference between the test and the analysis of results. By referring this value to the experimental data, $5.23 \%$ of relative error can be derived. This value, although slightly less accurate than the one obtained for brick elements, confirms that this method of modeling of adhesive joints is reliable and can be effectively used to simulate this type of structural connections.

However, when analysis time is compared (non-linear, large displacement static analysis with 50 load substeps): 24 seconds for the shell model and 103 seconds for the brick model, the advantage of using shell elements becomes clear. The computation time for the brick-based model was 4.29 times longer than for its simplified counterpart. Considering the size of the models, one can imaginatively scale this time efficiency to real-life problems, consisting of millions of elements (e.g., in the simulation of a full model car crash).

Despite some discrepancies with respect to the experimental results, all the joint strength values obtained showed a high level of correspondence with the data from the tests, proving that the CZM-based adhesive models are reliable and effective.

\section{CONCLUSIONS}

The paper has described a method of the modeling of adhesive bonds using the CZM model in conjunction with shell representation of the joints. The methods of building the FE representation of adhesive joints most often encountered in the literature assume the application of brick (volume) elements. Although they provide accurate results, the time needed for numerical analysis of such a system can be unacceptably long, because of an additional number of dof's introduced to the system. This is especially evident in large models, representing complicated structures, like a car or an airplane. In such cases, the application of three-dimensional, solid finite elements can be unfeasible. The CZM models described in the preceding paragraphs require a relatively small number of nodes, thus saving computational power and analysis time.

The investigation of the accuracy of the CZM shellbased FE representation of bonded joints presented in this article resulted in a positive verification of the proposed method. It has been shown that this method can be used for the modeling of adhesive joints, preserving the required accuracy of the results.

\section{References}

ANSYS Inc. ANSYS Theory Manual, Release 11. 2007.

Alfano G., Crisfield M.A., 2001, Finite element interface models for the delamination analysis of laminated composites: mechanical and computational issues. International Journal for Numerical Methods in Engineering, vol. 50, no. 7, pp. 1701-1736.

Godzimirski J., Komorek A., 2007, Wptyw kształtu połqczenia i sposobu obciażenia na trwałość zmęczeniowa połaczeń klejowych. Technologia i Automatyzacja Montażu, no. 2-3, pp. 116-119.

Godzimirski J., Rośkowicz M., 2008, Trwałość zmęczeniowa tworzyw adhezyjnych. Polimery, vol. 53, no. 10, pp. 737-742.

Hazimeh R., Challita G., Khalil K., Othman R., 2014, Finite element analysis of adhesively bonded composite joints subjected to impact loadings. International Journal of Adhesion and Adhesives, vol. 56, pp. 24-31, doi: 10.1016/j.ijadhadh.2014.07.012.

Jiang X., Kolstein M.H., Bijlaard F.S.K., 2013, Study on mechanical behaviors of FRP-to-steel adhesively-bonded joint under tensile loading. Composite Structures, vol. 98, pp. 192-201.

Korta J., Mlyniec A., Uhl T., 2015, Experimental and numerical study on the effect of humidity-temperature cycling on structural multi-material adhesive joints. Composites Part B: Engineering, pp. 621-630, doi:10.1016/j.compositesb.2015.05.020.

Korta J., Uhl T., 2013, Multi-material design optimization of a bus body structure. Journal of KONES: Powertrain and Transport, vol. 20, no. 1, pp. 139-146.

Lanzerath H., Nowack N., Mestres E., 2009, Simulation Tool including Failure for Structural Adhesives in Full-Car Crash Models. Technical report, SAE Technical Paper, 2009-01-0474. 
Lee H.K., Pyo S.H., Kim B.R., 2009, On joint strengths, peel stresses and failure modes in adhesively bonded double-strap and supported single-lap GFRP joints. Composite Structures, vol. 87, no. 1, pp. 44-54.

Rudawska A., 2009, The bonding joints strength of aluminum sheets in the aspect of inseparable joints assembly. Technologia i Automatyzacja Montażu, vol. 2, pp. 35-38.

Rudawska A., 2013, Wybrane zagadnienia konstytuowania polqczen adhezyjnych jednorodnych i hybrydowych. Politechnika Lubelska, Lublin.
Sugiman S., Crocombe A.D., Aschroft I.A., 2013, Experimental and numerical investigation of the static response of environmentally aged adhesively bonded joints. International Journal of Adhesion and Adhesives, vol. 40, pp. 224-237.

Tran V.D., Oudjene M., Méausoone P.J., 2014, FE analysis and geometrical optimization of timber beech finger-joint under bending test. International Journal of Adhesion and Adhesives, vol. 52, pp. $40-47$. 